\title{
21. SEISMIC VELOCITIES IN THE NORTHERN BARBADOS RIDGE ACCRETIONARY COMPLEX, SITE 9491
}

\author{
Sheila Peacock, ${ }^{2}$ Graham K. Westbrook, ${ }^{2}$ and Daniel P. Graham ${ }^{2}$
}

\begin{abstract}
Two vertical seismic profiles (VSPs) were recorded in Hole 949C of Ocean Drilling Program Leg 156 to determine $P$ - and $S$-wave velocity structure. The sources were an air gun suspended from the ship at zero offset, and ocean bottom explosive shots. Direct and reflected $P$-waves and mode-converted $S$-waves were recorded. Mode-converted $S$-waves downgoing and upgoing from the zero-offset VSP give an upper bound to $S$-wave velocities $\left(V_{s}\right)$ for the wedge. They originate from a thrust fault at $278 \mathrm{~m}$ below sea floor (mbsf) and show two low- $V_{s}$ layers, $492 \mathrm{~m} / \mathrm{s}$ between 245 and $278 \mathrm{mbsf}$ and $367 \mathrm{~m} / \mathrm{s}$ between $320 \mathrm{mbsf}$ and the décollement at $398 \mathrm{mbsf}$, each with a high-velocity cap (greater than $500 \mathrm{~m} / \mathrm{s}$ ). (Similar waves in Hole 948D were misinterpreted as tube waves.) A horizontal-layer model with anisotropy is an alternative to the dipping isotropic model that would explain the presence of mode-converted $S$-waves in the zero-offset VSP.

$S$-waves generated by the ocean-bottom shots were not received as intended, because the rapid increase of $S$-wave velocity with depth bent the raypaths away from the downhole seismometer array. Mode-converted reflected $S$-waves had a maximum velocity of $520 \mathrm{~m} / \mathrm{s}$, whereas water-surface reflected $P$-waves had maximum velocities no greater than $1730 \mathrm{~m} / \mathrm{s}$ at the base of the hole at $397 \mathrm{mbsf}$. A two-dimensional model derived by $P$-wave raytracing has a low-velocity zone $\left(V_{p}=1681 \mathrm{~m} / \mathrm{s}\right)$ at the base of the accreted wedge that is overlain by a higher-velocity zone $\left(V_{p}=1746 \mathrm{~m} / \mathrm{s}\right)$ between 100 and $200 \mathrm{mbsf}$. An $S H$ component of $P$-to- $S$ mode-converted reflected waves shows that the waves could have passed through or been reflected from an anisotropic layer with a non-vertical axis of symmetry, either within or just below the accretionary wedge.

The $S$-wave velocities are higher than laboratory values at zero effective pressure $(114-260 \mathrm{~m} / \mathrm{s})$. The low velocities at the base of the accretionary wedge indicate high porosity and overpressure, but if the porosity consists of horizontal cracks (of aspect ratio 0.1 ), the observed velocity reductions for vertically travelling $P$-waves can be produced by an increase in porosity of $1 \%$.
\end{abstract}

\section{INTRODUCTION}

Downhole measurements during Leg 156 showed that pore fluid pressure at the base of the Barbados accretionary wedge is as much as $90 \%$ of lithostatic pressure at Sites 947 and 948 and overpressured to an uncertain but probably more moderate degree at Site 949 (Shipley, Ogawa, Blum, et al., 1995; J.C. Moore et al., 1995; Fisher et al., 1996). The accretionary complex at these sites is made up of lowpermeability pelagic and hemipelagic clays (Shipley, Ogawa, Blum, et al, 1995). The décollement, which separates accreted sediments above from subducting sediments below, is believed to be a major channel of fluid escape from the accretionary complex (Moore et al., 1988). Thermal anomalies indicate that flow along it is probably intermittent (Fisher and Hounslow, 1990, Foucher et al., 1990). Shear fabrics are observed in clays from the décollement zone (Shipley, Ogawa, Blum, et al., 1995; Mascle, Moore, et al., 1988) but these do not enhance its permeability (Dewhurst et al., 1996); consequently, intermittent flow by hydrofracture is required to sustain flow along the décollement to the toe of the wedge and beyond (Brown et al., 1994).

\section{Previous Seismic Experiments}

One of the aims of the three previous seismic experiments in the area (Fig. 1; Bangs et al., 1990; Bangs and Westbrook, 1991; Shipley et al., 1994; Westbrook et al., 1993) has been to relate seismic properties to the state of stress of the accretionary complex, particularly

${ }^{1}$ Shipley, T.H., Ogawa, Y., Blum, P., and Bahr, J.M. (Eds.), 1997. Proc. ODP, Sci. Results, 156: College Station, TX (Ocean Drilling Program).

${ }^{2}$ School of Earth Sciences, University of Birmingham, Edgbaston, Birmingham B15 2TT, United Kingdom. s.peacock@bham.ac.uk the décollement. Seismic velocity and reflectivity are related via porosity to effective stress. The stress regime in the accretionary complex has been deduced by mapping these seismic properties and using lab and downhole data to relate velocity to porosity. Principal results of the previous experiments are:

1. The $P$-wave velocity increase with depth within the complex is less than expected for a normally pressured section, indicating that the complex is overpressured for most of its depth (Bangs et al., 1990).

2. The décollement reflection progressively changes polarity from positive at the toe of the wedge to negative a kilometer or so arcward. Brighter zones in the décollement reflection were interpreted as being caused by areas in which the pores were inflated by migrating pulses of high pressure fluid (Westbrook, 1991). At one point these reflections can be modeled with a 20 -m-thick low-velocity zone with velocity about $10 \%$ lower than in the layer above, which indicates a porosity increase of 15\% (Bangs and Westbrook, 1991). An alternative model (Shipley et al., 1994; Bangs et al., 1996) has a 12- to 16$\mathrm{m}$-thick décollement zone with velocities $10 \%-12 \%$ lower than in the wedge above, underlain by a zone with velocities $5 \%$ lower than in the wedge. Such large velocity contrasts could imply near-lithostatic fluid pressures reducing grain-tograin contact (Tobin et al., 1994), or even locally superlithostatic pressures causing dilation.

3. A three-dimensional survey (Fig. 1) mapped out zones of brighter negative amplitude from the décollement reflector in the close vicinity of the drill sites, as well as lower amplitude regions of both negative and positive polarity.

4. Models of mode-converted $S$-wave arrivals have required an average $S$-wave velocity of $317-470 \mathrm{~m} / \mathrm{s}$ within the accretionary complex, indicating a Poisson's ratio of over 0.45 (G.K. Westbrook et al., unpubl. data). 


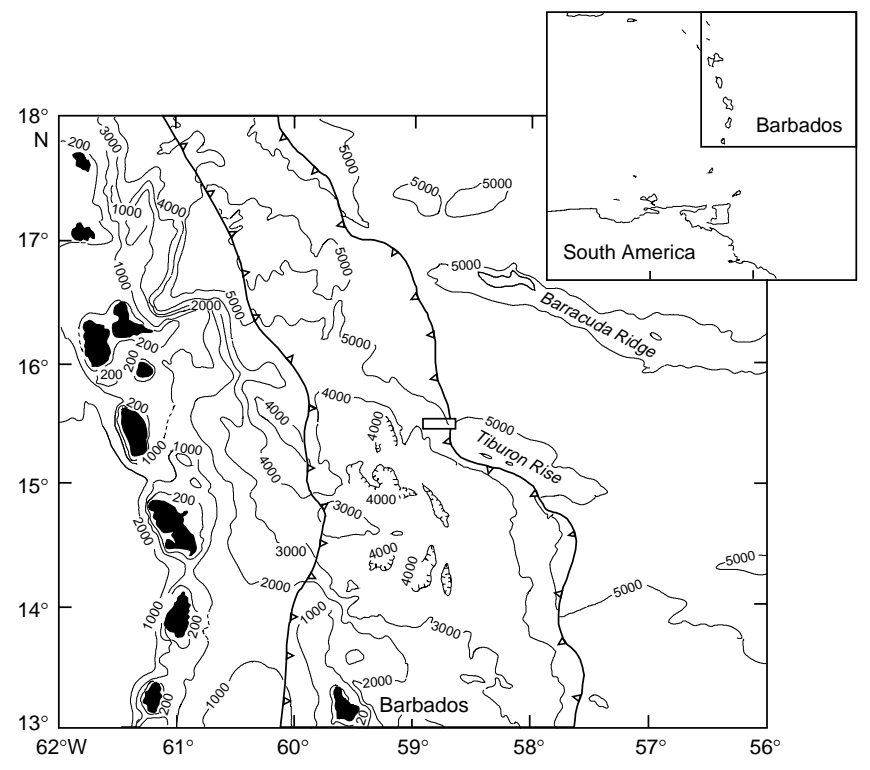

Figure 1. Map showing location of three-dimensional seismic survey on the North Barbados Ridge. Drill sites lie within three-dimensional survey area (box to northwest of Tiburon Rise).

\section{Aim of this Experiment}

Our aim was to use $S$-waves to detect low strength and hence high dilatancy in the accretionary complex. This was the first attempt to record within a borehole $S$-waves generated directly by ocean-bottom explosive shots. ( $S$-waves from similar shots in the same area [G.K. Westbrook et al., unpubl. data] and elsewhere [Kirk et al., 1991] have been recorded by ocean-bottom seismometers.) By knowing the exact start and end point of the $S$-waves, we hoped that we would be able to model their propagation, and in particular any shear-wave splitting. Seismic anisotropy along the raypath would cause shearwave splitting, which can be modeled with synthetic seismograms and interpreted in terms of the geometry and orientation of aligned cracks and mineral grains (Crampin, 1984, 1985; Bush and Crampin, 1991).

In the end, we did not record any direct $S$-waves, only $P$-to- $S$ mode-converted reflections and refractions. From these and modeconversions from a zero-offset vertical seismic profile (VSP) we determined a low $S$-wave velocity $(296-595 \mathrm{~m} / \mathrm{s})$ in the accretionary wedge above the décollement. $P$-waves, direct and reflected, were used to determine a $P$-wave velocity model complementing the models from the previous experiments. In this paper we describe:

1. acquisition and processing of the ocean-bottom shot data, including shot location;

2. analysis of the principal arrivals: $P$, mode-converted $S$, and tube waves;

3. investigation of the reason for the lack of direct $S$-waves, through synthetic seismograms and laboratory measurements of seismic properties (Appendix);

4. modeling of anisotropy implied by horizontal transverse component of polarization of mode-converted reflected $S$-waves and existence of mode-converted $S$-waves from the zero-offset VSP.

\section{ACQUISITION AND PROCESSING}

\section{Acquisition}

Our experiment was the downhole recording of 21 ocean-bottom explosive shots, with a five-level three-component borehole seis- mometer array. We also used data from a zero-offset VSP in which signals from an air-gun source suspended from the drillship were recorded by the same array (Shipboard Scientific Party, 1995b).

Both experiments were performed in Hole 949C, which is about $2 \mathrm{~km}$ arcward of the deformation front of the accretionary complex. The décollement at Site 949 lies between $400 \mathrm{~m}$ of accreted claystone above and a similar thickness of relatively undeformed subducting sediment beneath (Fig. 2).

At the time of the experiments, the borehole had not been drilled to total depth, but to $398 \mathrm{~m}$ below seafloor (mbsf), to which depth it was cased with $339.7-\mathrm{mm}$ diameter (13 3/8 in) casing of 1 -cm-thick steel. The casing had been cemented to the formation, but a cement bond log showed that cementing was poor or absent above about 300 mbsf (Shipboard Scientific Party, 1995b). The 60.96-m-long seismometer array (five elements at 15.24-m spacing) was set at 397.2$336.2 \mathrm{mbsf}$ for Shots 1-10 and 336.2-275.3 mbsf for Shots 11-21.

Each of the five elements of the seismometer array (Schlumberger Array Seismic Imager) contained a three-component set of acceleration sensors and was magnetically clamped to the inside of the casing. The two horizontal sensors in each element were oriented at $45^{\circ}$ to the clamping direction, with positive polarity indicating acceleration away from the borehole wall. The vertical component had positive polarity for upward acceleration. Two hydrophones (Hall-Sears) were suspended from the ship, about $67 \mathrm{~m}$ apart (Fig. 3), to record the water wave from the shots and constrain their azimuth. Their depth was calculated for each shot from the arrival delay of the surface ghost reflection. Signals received by these and the seismometer array were digitized at $0.5-\mathrm{ms}$ sample interval, then anti-alias filtered at $150 \mathrm{~Hz}$ and resampled at 2-ms sample interval before recording. The anti-alias filter reduced the amplitude at the $250-\mathrm{Hz}$ Nyquist frequency by $70 \mathrm{~dB}$.

Each shot consisted of four $2.7-\mathrm{kg}$ charges of cast Pentolite detonated electrically by a 24-hr timer circuit (Kirk et al., 1991; Westbrook et al., 1993). They were put over the side of the ship in weighted plastic tubes that have a calculated terminal velocity in water of $3.3 \mathrm{~m} / \mathrm{s}$. The shots were deployed in a pattern to give as wide a variety of azimuth and incidence angle as possible within a limit of $1 \mathrm{~km}$ from the borehole (Fig. 4). The deployment pattern was also intended to keep the shots at least $200 \mathrm{~m}$ apart to prevent damage to the timers of adjacent shots. Shots 1,7 , and 18 did not detonate or were not recorded (Shipboard Scientific Party, 1995b)

\section{Typical Data Records}

Figure 5 shows typical data records from the two positions of the geophone array (397-366 m for Shot 6, 366-275 m for Shots 11 and 14). Direct downgoing and reflected upgoing $P_{-}, S$-, and tube waves are marked. Not shown is the water surface reflected $P$-wave, which arrives about $6 \mathrm{~s}$ after the direct arrivals (its apparent velocities are shown in Figure 6), nor the section of seismogram 2.5-4 s after the $P$-wave arrival, where direct $S$-wave arrivals were expected but not observed. Figure 7 shows the zero-offset VSP.

\section{Processing}

The fast-detonating Pentolite gave very high frequency signals, particularly as the geophones were acceleration sensors. The frequency band was about 100 to $250 \mathrm{~Hz}$ (the Nyquist frequency for the 2ms sample interval). The horizontal components were rotated to radial and transverse to the direction of polarization of the $P$-wave first arrival (DiSiena et al., 1984), using a 20 -ms window beginning at the first break. The 2-ms sample interval of the original recording was too large, because there was appreciable seismic energy at the Nyquist frequency of $250 \mathrm{~Hz}$. We were unable to use a smaller interval because we needed long records $(30 \mathrm{~s})$, to allow for uncertainty in the detonation time of the shots and to record the water surface reflected arrival. Because of memory limits in the Schlumberger Maxis 
Common midpoint $1200 \quad 1.5 \mathrm{~km} \quad 1300$

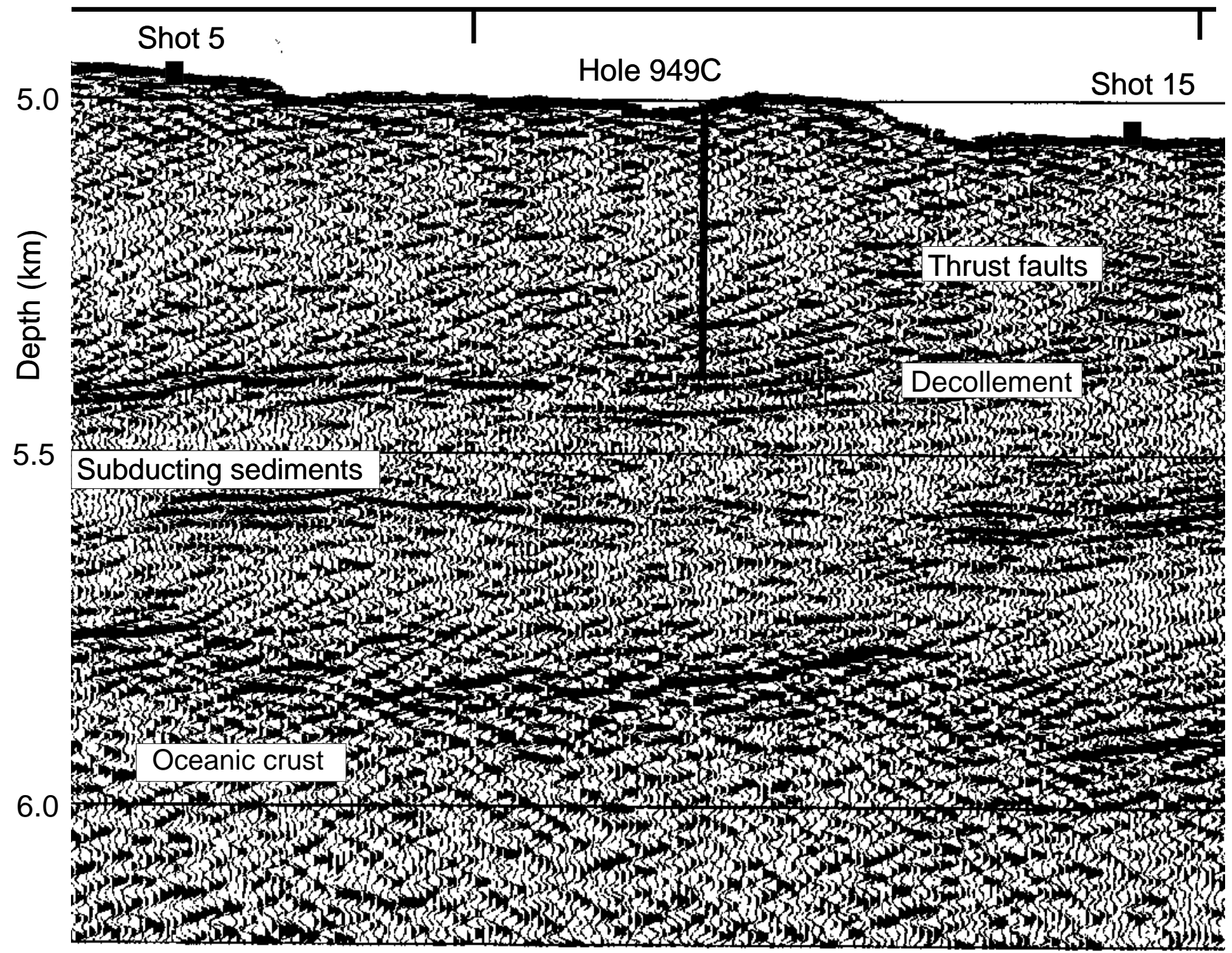

Figure 2. Seismic section, Line 736 of three-dimensional survey (G.F. Moore et al., 1995), showing Hole 949C and major structures.

recording system, $2 \mathrm{~ms}$ was the shortest sample interval at which we could record $30 \mathrm{~s}$ of data.

\section{RESULTS}

Arrivals

The arrivals identified at the seismometer array were:

1. P-wave first arrival. The $P$-wave first arrival is downgoing and has apparent velocity across the array of 2,822-76,200 m/s.

2. Later fast downgoing waves. Shots $9,14,15,16$, and 17, all of which are on the shelf below the scarp to the east of the borehole, show a strong downgoing wave with apparent velocity slightly less than the direct $P$, between the $P$ - and tube-wave arrivals.

3. Upgoing waves with apparent velocities above $1800 \mathrm{~m} / \mathrm{s}$. These are presumed to be $P$-wave reflections, from the basement or interfaces within the subducting sediments. When projected downward they intersect the downgoing wave at depths of about 400 and 600 mbsf.
4. Upgoing waves, apparent velocity between 1000 and $1800 \mathrm{~m} /$ $s$. Arrivals with apparent velocities between 1000 and $1800 \mathrm{~m} /$ $\mathrm{s}$ are probably tube waves created by mode conversion of direct or reflected $P$-waves striking the base of the borehole.

5. Upgoing waves, apparent velocity less than $1000 \mathrm{~m} / \mathrm{s}$. Only the arrivals with lowest apparent velocities can be ascribed with certainty to $S$-waves. Shots 6 and 11 show these most clearly: apparent velocity $520 \mathrm{~m} / \mathrm{s}$ for Shot 6 and $381 \mathrm{~m} / \mathrm{s}$ for Shot 11 . When projected downward they intersect the $P$-wave first arrival at about $420 \mathrm{~m}$ for Shot 6 and $390 \mathrm{~m}$ for Shot 11 . These are likely to be mode-converted $S$-waves from the décollement at $400 \mathrm{~m}$ for Shot 11 and the lower "décollement" reflector at $430 \mathrm{~m}$ for Shot 6

6. Tube waves. Tube waves were the strongest arrivals from all shots except 17 . These arrivals were identified as tube waves because (a) their velocity across the seismometer array was independent of the shot distance and (b) one or more clear multiples with the same apparent velocity came in at time intervals equal to twice the borehole length divided by the apparent velocity. We think that the tube waves are generated at the top of the borehole by the water wave coming directly from the shot, 


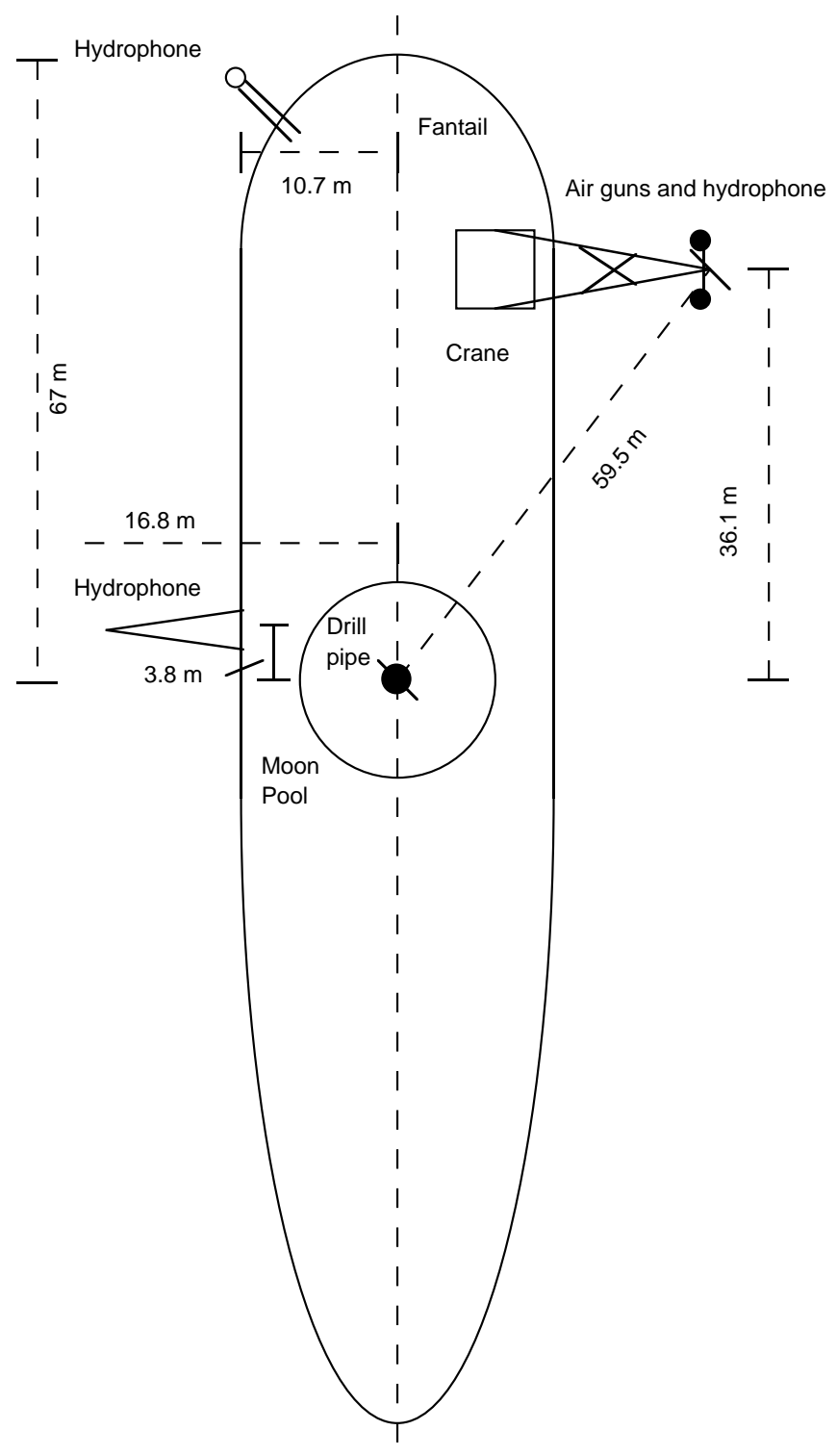

Figure 3. Positions of hydrophones and air gun suspended from ship.

which is the largest phase produced by similar ocean-bottom shots recorded by ocean-bottom seismometers (G.K. Westbrook et al., unpubl. data).

7. The P-wave reflected from the water surface. This arrived about $6 \mathrm{~s}$ after the direct waves and had apparent velocity $1590-2200 \mathrm{~m} / \mathrm{s}$.

\section{Shot Locations}

The position of the ship at deployment of the shots was known to $\pm 10 \mathrm{~m}$ from the automatic station keeping system (which processed signals from two seafloor sonar beacons received by microphones in the hull, Fig. 4). Ocean currents in the 5-km water column have caused ocean-bottom shots and seismometers deployed in previous experiments to drift up to several hundred meters in various directions (T. Shipley, pers. comm., 1994). The surface current is from east to west, but at depth a current is thought to follow the strike of the ridge from north to south. The ocean-bottom shots fall at terminal velocity $3.3 \mathrm{~m} / \mathrm{s}$ (Westbrook et al., 1993) and take about $25 \mathrm{~min}$ to reach the seafloor.

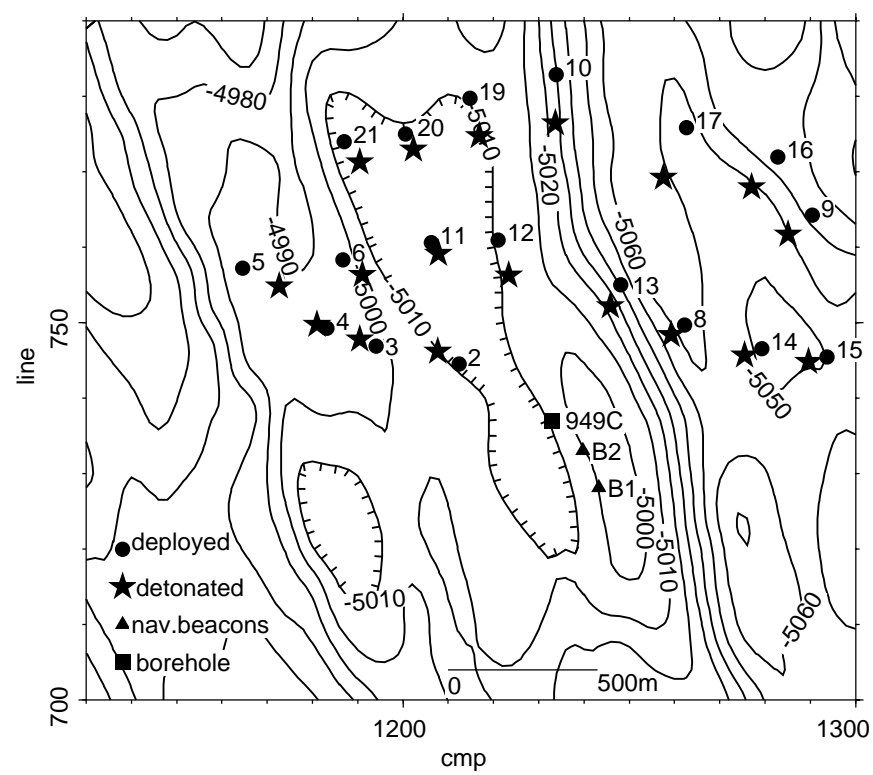

Figure 4. Bathymetric map showing Hole 949C and positions of deployment and detonation of the ocean-bottom shots. Bathymetry in meters, from threedimensional survey (Shipley et al., 1994). Circles show deployment positions, and stars show calculated detonation positions of shots. Triangles show positions of sonar beacons used by the ship's automatic station keeping system. Coordinates are line and common-midpoint (CMP) number of threedimensional survey: line spacing is $25 \mathrm{~m}$, CMP spacing $15 \mathrm{~m}$. The map is $2.55 \mathrm{~km}$ across. Fringes on contours show bathymetric lows.

Arrivals that can be used (in pairs) for locating the shots are (a) the direct $P$-wave at the seismometer array; (b) the water-surface reflection at the seismometer array; (c) the tube wave at the seismometer array; (d) the direct $P$-wave at the two surface hydrophones. The pair (b) and (c) were used to find the distance of the shots from the borehole top, checked with the pair (a) and (c). (d) were used alone to determine the shot azimuth from the borehole.

\section{Shot Distance}

The vertical $P$-wave velocity structure is well constrained by the zero-offset VSP (Shipboard Scientific Party, 1995b) and was used to calculate traveltimes for the water surface reflected wave. This wave arrives nearly vertically at the seismometer array because of the large water depth (the greatest deviation from vertical, for the farthest shots, is about $6^{\circ}$ ). The tube-wave velocity is also well constrained by the delay of tube-wave multiples. When these two arrivals are used to determine the shot distance, the most important unknowns are the velocity of the wave traveling from the shot to the top of the borehole, which initiates the tube wave, and the shot depth.

"Solver," a subroutine of the Microsoft Excel spreadsheet, was used to calculate shot distances. It worked by searching for a value of shot distance that minimized the sum of squares of traveltime residuals (observed minus calculated arrival times) from the five array geophones.

We assumed that the wave initiating the tube wave was a water wave, and assigned to it a velocity of $1540 \mathrm{~m} / \mathrm{s}$, derived from the water depth, the water bottom temperature of $2.35^{\circ} \mathrm{C}$ (Shipboard Scientific Party, 1995b) and a salinity of $34.86 \mathrm{ppm}$. Errors of $0.5 \%$ in this value $(3 \mathrm{~m} / \mathrm{s})$ lead to changes of $\pm 2 \mathrm{~m}$ in shot distance and little change in origin time.

Water depth was taken initially from the shot deployment position on the bathymetric map derived from the three-dimensional seismic reflection survey (Shipley et al., 1994), corrected for a mean water column velocity of $1508 \mathrm{~m} / \mathrm{s}$ (G.F. Moore et al., 1995) and contoured 

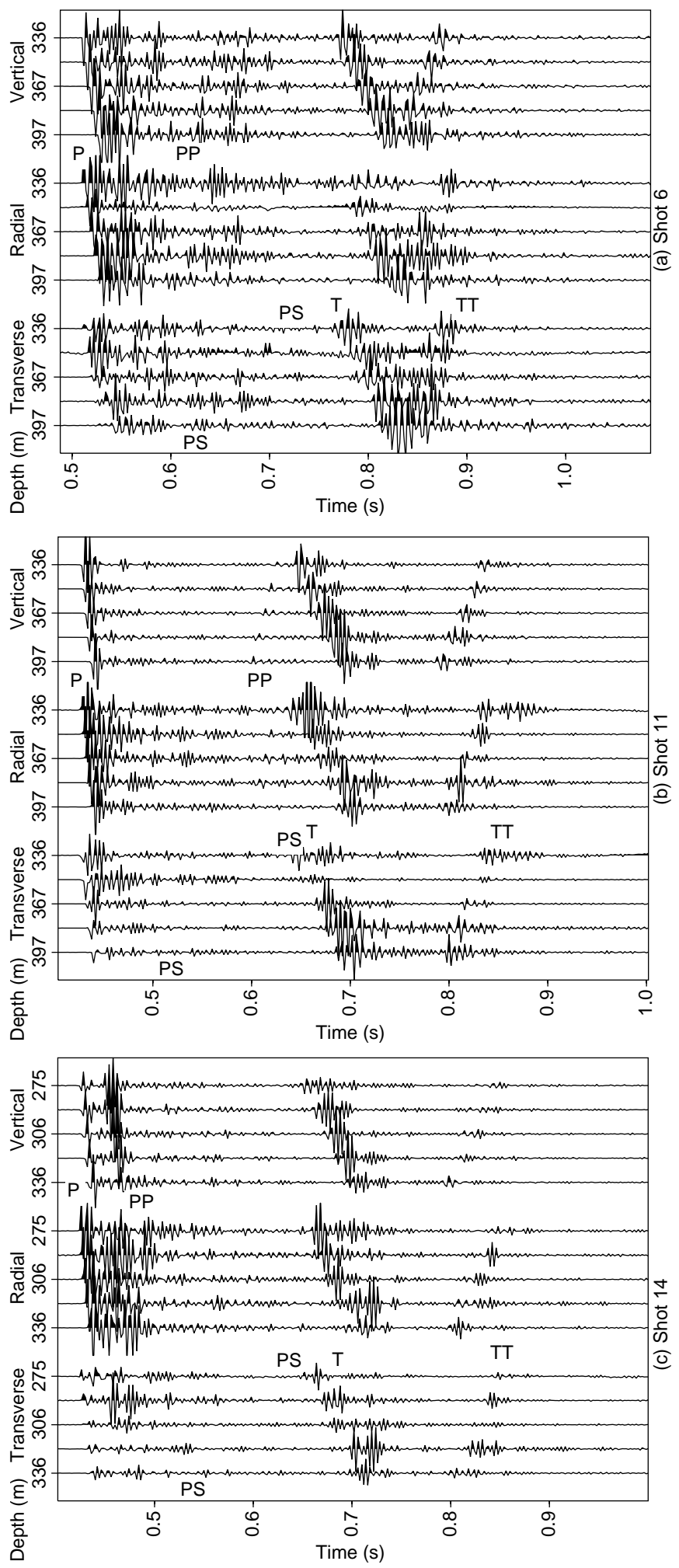

Figure 5. (A) Shot 6, (B) Shot 11, and (C) Shot 14, records from the 5-level, three-component seismometer array. Records from vertical, radial, and transverse components are shown from the five geophone levels. From top to bottom, for Shot 6, 336.24, 351.58, 366.72, 381.96, and 397.20 m, and for Shots 11 and $14,275.33,290.57,305.81,321.05$, and $336.29 \mathrm{~m}$. Downgoing $P$, upgoing $P(\mathrm{PP})$, mode-converted $S(\mathrm{PS})$ and downgoing and upgoing tube (T, TT) waves are labeled.

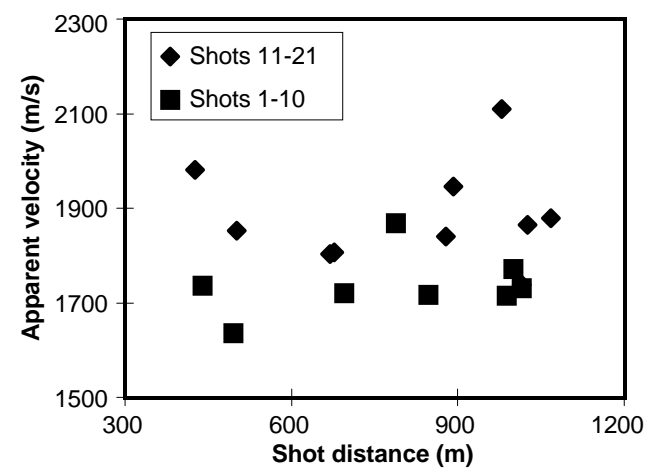

Figure 6. Apparent velocity of water surface reflected $P$-wave across seismometer array. Squares $=$ Shots $1-10$ (array at 397.2-336.2 mbsf); diamonds = Shots 11-21 (array at 336.2-275.3 mbsf).

at 2-m intervals. These depths were accurate to $\pm 10 \mathrm{~m}$. The location routine was run, then the depths were modified to those of the resulting detonation positions and the shot location re-iterated. The depth uncertainty of $10 \mathrm{~m}$ translates directly into a distance uncertainty of $10 \mathrm{~m}$ and origin time change of $0.007 \mathrm{~s}$ (further away and earlier for increased depth). These are the distances listed in Table 1.

\section{Azimuth}

Shot azimuths calculated from arrival times at the two hydrophones were poorly constrained, because the hydrophones were too close together (nominally $64.2 \mathrm{~m}$ ) compared with the raypath length and because of the uncertainty in the position of the ship (the position data from the automatic station keeping system for the shot detonation times were not preserved). In the end, the deployment azimuth was used for all shots (Table 1).

\section{$P$-wave Velocities from Sea-surface Reflections}

The apparent velocity of the sea-surface reflection across the seismometer array gives an estimate of the maximum $P$-wave velocity at those depths (because the raypath is nearly vertical). The values (found by least-squares regression on the arrival times) are around $1740 \mathrm{~m} / \mathrm{s}$ for the lower position of the array (397-336 mbsf; mean slowness $0.574 \pm 0.028 \mathrm{~ms} / \mathrm{m}$ ) and $1812 \mathrm{~m} / \mathrm{s}$ for the upper position (275-336 mbsf; mean slowness $0.514 \pm 0.037 \mathrm{~ms} / \mathrm{m}$ ) and show no correlation with distance from the borehole (Fig. 6).

\section{Low Velocity Arrivals on Zero-offset VSP Horizontal Components}

The horizontal component records from the zero-offset VSP in Hole 949C are noisy (Fig. 7), but show clear phases with low apparent velocity traveling both upward and downward. We suggest that these are $P$-to- $S$ mode-converted waves. They coincide with the downgoing $P$-wave at $275-300 \mathrm{~m}$. Their apparent velocities (from least-squares regression on arrival time picks, Fig. 8) are between 367 and $595 \mathrm{~m} / \mathrm{s}$. They are not tube waves, which have an apparent velocity of $1330 \mathrm{~m} / \mathrm{s}$.

\section{INTERPRETATION}

\section{Direct and Reflected $P$-wave Modeling of Ocean-bottom Shots}

The $P$-wave first arrivals were modeled by two-dimensional raytracing (using program GXII from GX Technology). The shots to east 
Table 1. Shot deployment and detonation locations, Hole 949C.

\begin{tabular}{|c|c|c|c|c|c|c|}
\hline \multirow[b]{2}{*}{ Shot } & \multirow{2}{*}{$\begin{array}{c}\begin{array}{c}\text { Detonation } \\
\text { position }\end{array} \\
\text { Distance } \\
\text { from hole } \\
(\mathrm{m})\end{array}$} & \multicolumn{2}{|c|}{ Deployment position } & \multirow[b]{2}{*}{$\begin{array}{l}\text { Water } \\
\text { depth } \\
(\mathrm{m})\end{array}$} & \multicolumn{2}{|c|}{ Times } \\
\hline & & $\begin{array}{l}\text { Distance } \\
\text { from hole } \\
\quad(\mathrm{m})\end{array}$ & $\begin{array}{l}\text { Azimuth } \\
\text { from hole } \\
\left(\mathrm{N}^{\circ} \mathrm{E}\right)\end{array}$ & & $\begin{array}{c}\text { Recording } \\
\text { start time } \\
\text { (local time) }\end{array}$ & $\begin{array}{c}\text { Detonation } \\
\text { time } \\
\text { (s after start) }\end{array}$ \\
\hline 2 & 443.3 & 363.0 & -58.9 & 5010 & $1: 10: 38$ & 3.323 \\
\hline 3 & 691.9 & 632.4 & -67.1 & 4994 & $1: 20: 36$ & 6.606 \\
\hline 4 & 841.8 & 807.0 & -67.8 & 4992 & $1: 30: 36$ & 5.444 \\
\hline 5 & 1009.0 & 1144.0 & -63.8 & 4991 & $1: 40: 36$ & 8.394 \\
\hline 6 & 794.3 & 874.3 & -52.4 & 5002 & $1: 50: 35$ & 8.210 \\
\hline 8 & 487.0 & 539.6 & 54.1 & 5058 & $2: 10: 35$ & 9.918 \\
\hline 9 & 994.6 & 1097.0 & 51.7 & 5061 & $2: 20: 35$ & 6.006 \\
\hline 10 & 986.4 & 1148.0 & 0.6 & 5025 & $2: 30: 35$ & 10.116 \\
\hline 11 & 670.5 & 714.0 & -34.2 & 5017 & $3: 30: 34$ & 9.217 \\
\hline 12 & 503.7 & 625.0 & -16.7 & 5009 & $3: 40: 34$ & 10.701 \\
\hline 13 & 425.8 & 504.7 & 26.7 & 5026 & $3: 50: 34$ & 8.698 \\
\hline 14 & 672.7 & 734.7 & 71.1 & 5053 & $4: 00: 34$ & 10.319 \\
\hline 15 & 870.7 & 935.0 & 77 & 5049 & $4: 10: 33$ & 10.351 \\
\hline 16 & 1018.0 & 1150.0 & 40.5 & 5060 & $4: 20: 34$ & 10.636 \\
\hline 17 & 885.4 & 1069.0 & 24.6 & 5061 & $4: 30: 34$ & 10.308 \\
\hline 19 & 973.5 & 1104.0 & -14.4 & 5012 & $4: 50: 34$ & 9.707 \\
\hline 20 & 1010.7 & 1067.5 & -27.1 & 5013 & $5: 00: 34$ & 3.693 \\
\hline 21 & 1068.3 & 1153.2 & -36.7 & 5017 & $5: 10: 33$ & 12.231 \\
\hline
\end{tabular}

Notes: Latitude $=15^{\circ} 32.214^{\prime} \mathrm{N}$, longitude $=58^{\circ} 42.855^{\prime} \mathrm{W}$. Water depth $(\mathrm{m})=5006.6$. The deployment azimuths were used in subsequent processing.

and west of the borehole were modeled separately (Fig. 9). The model consists of layers within which $P$-wave velocity varies vertically (Table 2). A thrust fault intersects the model borehole at $290 \mathrm{~m}$, corresponding to the one observed in the three-dimensional seismic reflection survey and deduced from stratigraphic inversion in core from Hole 949B (Shipboard Scientific Party, 1995b; G.F. Moore et al., 1995).

Observed and synthetic arrivals for Shot 14 are shown as an example (Fig. 10). To match the low apparent velocities of $P$-waves across the seismometer array, the model has a high-velocity layer between about 100 and 150 mbsf, over lower-velocity layers that refract the raypaths toward vertical. Still, the $P$-wave velocities in layers at the depth of the array are lower than those derived from direct $P$ wave traveltimes from the zero-offset VSP $(1837 \mathrm{~m} / \mathrm{s}$ above $300 \mathrm{~m}$, $1818 \mathrm{~m} / \mathrm{s}$ below [Shipboard Scientific Party, 1995b]).

\section{Slow Arrivals on Zero-offset VSP}

The interfaces causing these arrivals, at about 278 and $300 \mathrm{~m}$, coincide with the level at which the $P$-wave velocity rises sharply as seen in the vertical-component traveltimes (Shipboard Scientific Party, 1995b). They are close in depth to the thrust fault at $290 \mathrm{~m}$ in core from Hole 949B. This thrust is also required in our model of the direct $P$-waves from the ocean-bottom shots.

There is a clear low velocity zone at the bottom of the hole below $350 \mathrm{~m}$, also in agreement with the $P$-wave results.

\section{Slow Arrivals in Hole 948D VSP}

A similar downgoing wave in the VSP in Hole 948D (Shipboard Scientific Party, 1995a) with apparent velocity $641-957 \mathrm{~m} / \mathrm{s}$, was interpreted as a tube wave. We now believe that it too is a downgoing $S$-wave, originating at an interface at about $150 \mathrm{~m}$ (at which there is a jump in $P$-wave velocity). Hole $948 \mathrm{D}$ was cased with the same diameter and thickness of steel casing as Hole 949C and is therefore likely to have a similar tube wave velocity of around $1300 \mathrm{~m} / \mathrm{s}$. The higher $S$-wave velocity in Hole 948D, like the higher $P$-wave velocity, probably indicates greater compaction at this site, which is in an older, thicker part of the accretionary wedge.

\section{Modeling of Zero-offset VSP}

The zero-offset VSP was modeled with a full-waveform anisotropic reflectivity program, Aniseis (Taylor, 1992). As it uses the reflectivity method, Aniseis works with models consisting of plane homo- geneous parallel layers. A vertical velocity gradient is simulated by many thin horizontal layers.

Two models were tried: one was restricted to vertical incidence on horizontal layers and used anisotropy to create a $P$ - to $S$-mode converted waves; the other used dipping isotropic layers to create the mode-converted waves (Table 3; Fig. 11). The anisotropic model had anisotropic layers above and below the reflectors at 278 and $298 \mathrm{~m}$, to replicate the observed horizontal components of motion of the direct $P$-wave.

There is no control on the nature of the anisotropy that causes the mode-conversions, except that its axis of symmetry cannot be parallel nor perpendicular to the interfaces. Rather than arbitrarily assigning anisotropic elastic moduli, we used Hudson's $(1981,1986)$ theory of wave propagation in cracked solids to generate a "realistic" medium with aligned-crack anisotropy. The cracks were water-filled and had an aspect ratio of 0.01 and a crack density of 0.02 (crack density is $n a^{3} / \mathrm{V}$ where $n$ is the number of cracks of radius $a$ in volume $V$ of rock), which corresponds to a crack porosity of 0.0002 .

For the isotropic model we chose a dip of $5^{\circ}$. The reflection sections through the site show a small dip on the thrust fault reflector at 290 mbsf (G.F. Moore et al., 1995).

We designed the anisotropic model to give mode conversion at both interfaces (278 and $298 \mathrm{mbsf}$ ) and a horizontal component to the downgoing $P$ first motion. The model was anisotropic with symmetry axes not vertical nor horizontal. A change of axis orientation (crack orientation) rather than a change in material, was used to create the mode-conversion at 298 mbsf. Above 278 mbsf cracks strike $317^{\circ}$ from the "radial" direction and dip $28^{\circ}$ from horizontal; between 278 and $298 \mathrm{mbsf}$ they strike $344^{\circ}$ and $\operatorname{dip} 53^{\circ}$, and beneath $298 \mathrm{~m}$ they strike $79^{\circ}$ and dip $70^{\circ}$. Within the 5-m-thick "décollement" layer, they are vertical and strike $45^{\circ}$. All of these orientations are arbitrarily chosen as the orientation of the downhole seismometer is unknown.

We estimated velocities and densities of the uppermost three layers. Lower limits were set by the mudline core in Hole 949A, which penetrated to $2.8 \mathrm{mbsf}$ and had physical properties: density $=1420$ $1510 \mathrm{~kg} / \mathrm{m}^{3}, P$-wave velocity $=1432-1481 \mathrm{~m} / \mathrm{s}, S$-wave velocity $=$ $36-38 \mathrm{~m} / \mathrm{s}$ (at lab temperature and pressure). Inversion of Scholte wave dispersion in records from ocean-bottom shots of the 1993 seismic experiment, gives $S$-wave velocities of $60-230 \mathrm{~m} / \mathrm{s}$ in the top 75 $\mathrm{m}$ of sediment at Site 948 (Westbrook et al., 1993).

For both the models, mode-converted $S$ reflections and refractions from the interfaces at 278 and $298 \mathrm{~m}$ (top and bottom of Layer 6) match the observed arrivals (Fig. 12, 13). 

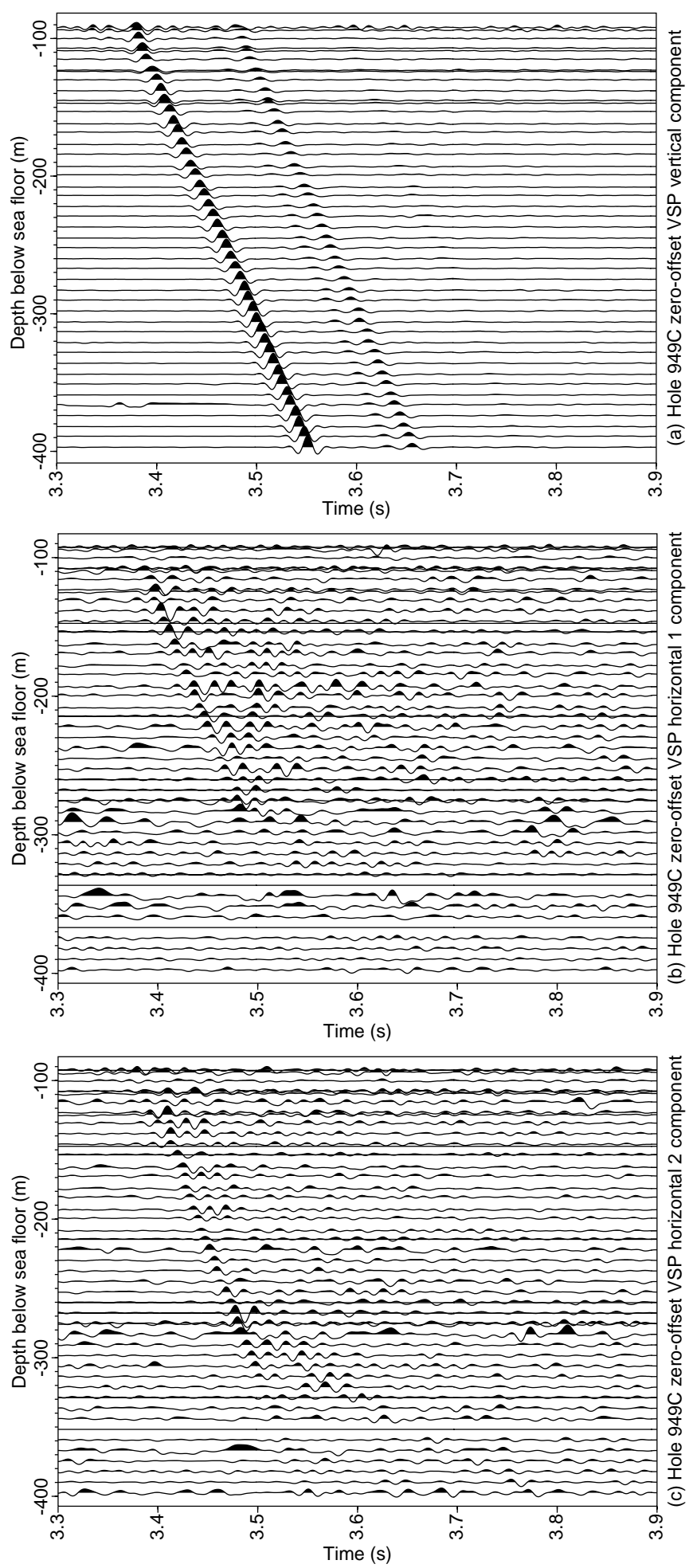

Figure 7. Record sections from air gun zero-offset VSP in Hole 949C, stacked and filtered $(5-50 \mathrm{~Hz})$. A. Zero-offset VSP vertical component. B. Zero-offset VSP horizontal 1 component. C. Zero-offset VSP horizontal 2 component.

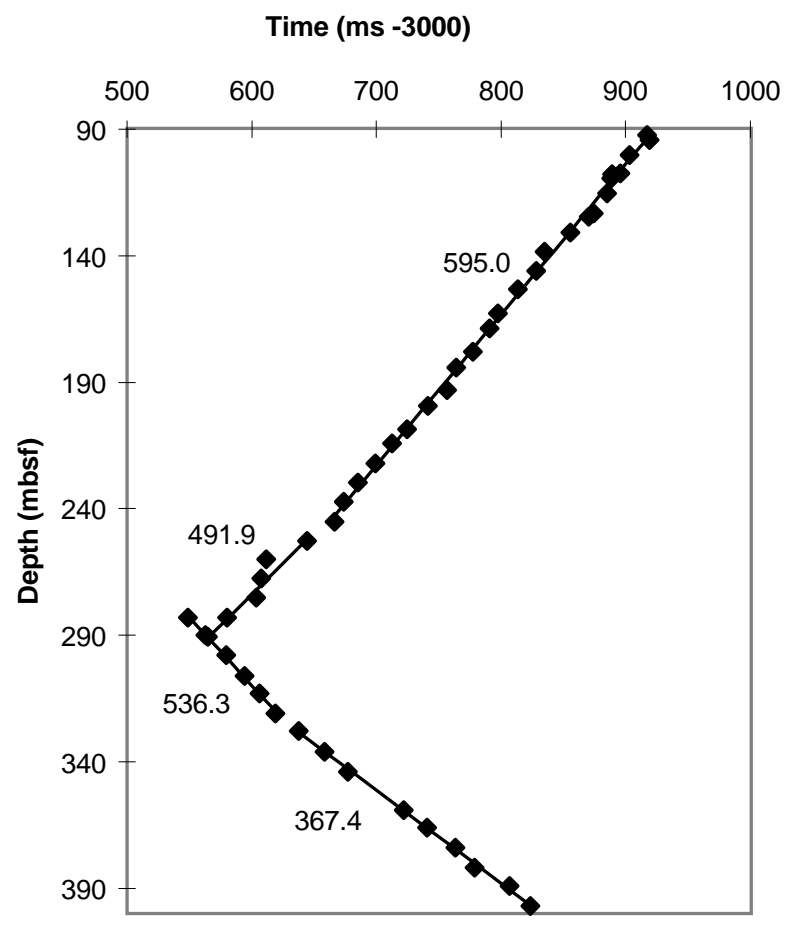

Figure 8. Traveltimes of low apparent velocity arrivals on zero-offset VSP in Hole 949C. Apparent velocities in $\mathrm{m} / \mathrm{s}$ (from least-squares line fits) are shown.

In Figure 12 only the anisotropic synthetic seismograms are shown. The seismograms from the dipping isotropic model were very similar except that there was no energy in the transverse component.

The synthetic horizontal component geophones have the same orientation at all levels, but the orientations of the observed horizontals is unknown and may vary up the profile. This makes it impossible to distinguish between anisotropy and dip as causes of the mode conversion of the vertically traveling $P$-waves. For dipping isotropic layers the polarizations of $P$ - and $S$-waves would be confined to the vertical plane perpendicular to the strike of the dipping interface, but for anisotropic layers the polarizations would be out-of-plane.

\section{Direct $\boldsymbol{P}$-wave Arrivals from Ocean-bottom Shots- Modeling}

We attempted to model all the shots with the same horizontally layered anisotropic model as for the zero-offset VSP. The traveltimes of the synthetic $P$-wave first arrival from the zero-offset VSP model matched the observed $P$-wave traveltimes from the ocean-bottom Shots $5,10,11,12,13$, and 17 . They were $2-3 \mathrm{~ms}$ long for Shots 15 , 19, 20, and 21 and up to $10 \mathrm{~ms}$ short for Shots $2,4,6,8,9,14$, and 16. These mismatches in absolute traveltime probably arise from the uncertainty in the shot locations and depths and two- and threedimensional heterogeneity not included in the model. They do not correlate with the shot azimuth or recording depth.

The $P$-wave direct arrivals for Shots 3 through 9 (but not 2 or 10) had higher than observed apparent velocities across the seismometer array. The observed apparent velocity was matched by reducing the velocity of the layer just above the décollement to $1680 \mathrm{~m} / \mathrm{s}$. This model produced the seismograms in Figure 14. 


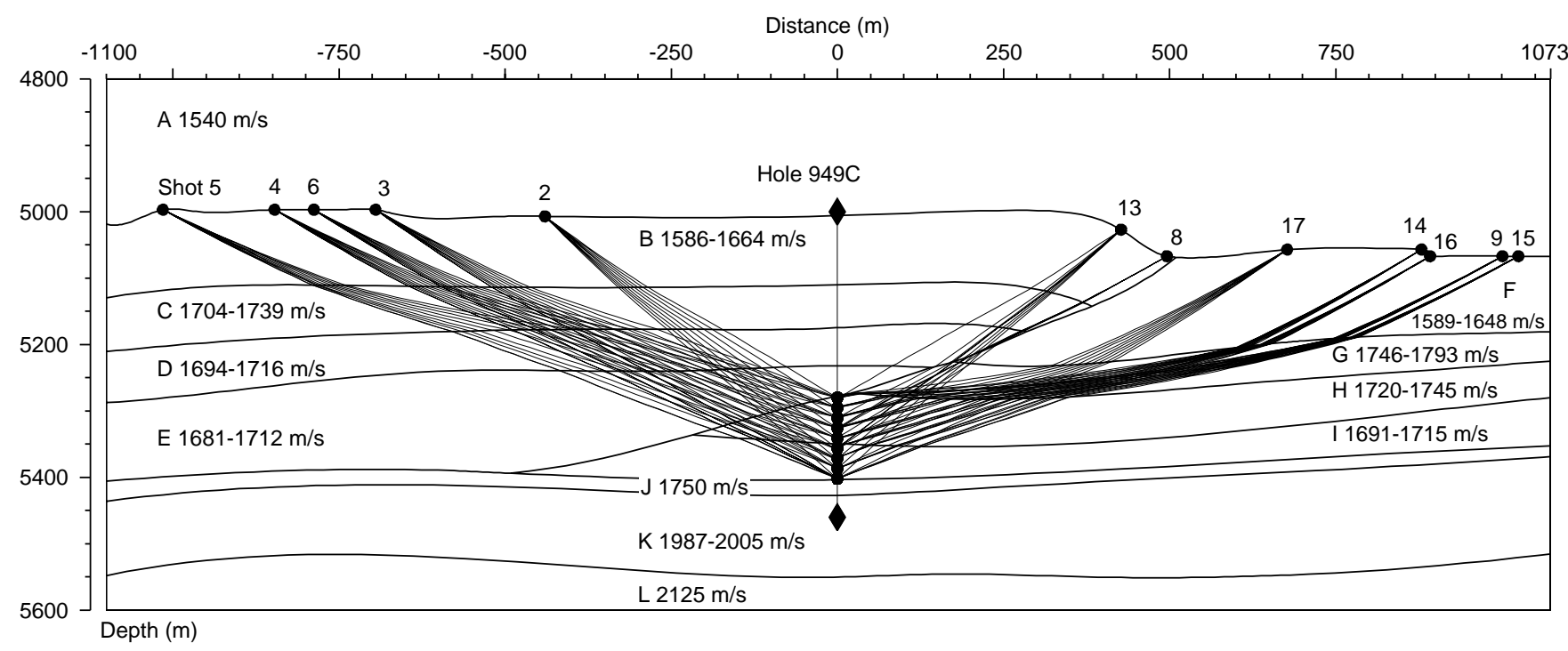

Figure 9. $P$-wave raypaths through two-dimensional model. The shots are projected onto an east-west section through the borehole. Velocities of model layers A to $L$ are given in Table 2. The velocities shown are those at the highest and lowest points of each layer.

Table 2. Parameters of two-dimensional model used for $P$-wave ray tracing.

\begin{tabular}{ccccc}
\hline Layer & $\begin{array}{c}\text { Density } \\
\left(\mathrm{kg} / \mathrm{m}^{3}\right)\end{array}$ & $\begin{array}{c}P \text {-wave velocity } \\
\text { at highest point } \\
(\mathrm{m} / \mathrm{s})\end{array}$ & $\begin{array}{c}\text { Velocity } \\
\text { gradient } \\
(/ \mathrm{s})\end{array}$ & $\begin{array}{c}P \text {-wave } \\
\text { velocity at } \\
\text { lowest point }\end{array}$ \\
\hline $\mathrm{A}$ & 1941 & 1540 & 0 & 1540 \\
$\mathrm{~B}$ & 1968 & 1586 & 0.6 & 1664 \\
$\mathrm{C}$ & 1996 & 1704 & 0.5 & 1739 \\
$\mathrm{D}$ & 1991 & 1694 & 0.2 & 1716 \\
$\mathrm{E}$ & 1989 & 1681 & 0.2 & 1712 \\
$\mathrm{~F}$ & 1957 & 1589 & 0.6 & 1648 \\
$\mathrm{G}$ & 2004 & 1746 & 0.5 & 1793 \\
$\mathrm{H}$ & 1996 & 1720 & 0.2 & 1745 \\
$\mathrm{I}$ & 1988 & 1691 & 0.2 & 1715 \\
$\mathrm{~J}$ & 2005 & 1750 & 0 & 1750 \\
K & 2069 & 1987 & 0.1 & 2005 \\
$\mathrm{~L}$ & 2105 & 2125 & 0.3 & - \\
\hline
\end{tabular}

\section{Reflected $S$-wave from Ocean-bottom Shots-Modeling}

The upgoing reflected wave in Shot 6, originating from about 30 $\mathrm{m}$ below the bottom of the borehole, is most visible on the transverse component (Fig. 5). This requires a $P$-to-SH mode conversion, which is impossible in an isotropic model or a horizontally layered anisotropic model with rotational symmetry about a vertical axis. The observed polarization can be modeled in two ways: by adding anisotropy to the layer containing the geophones, or by making the layer below the reflecting interface anisotropic (Liu et al., 1990; Fig. 13; Table 3). The observations put little constraint on the anisotropy, other than that for the anisotropic layer below the reflecting interface, the plane of incidence of the waves not be a plane of mirror symmetry.

To generate $P$-to- $S H$ mode-converted reflections from the appropriate depths for Shots 6 and 11, two anisotropic reflecting layers were included to simulate the observed "double décollement." The anisotropy has hexagonal symmetry about a horizontal axis at azimuth $45^{\circ}$ from the shot-borehole direction (but cracks with strike in many other directions including perpendicular to this would also generate $S H$-waves). The cracked medium properties were appropriate to vertical parallel water-filled cracks of aspect ratio 0.01 and crack density 0.04 .

We have not tried to model the detailed particle motion of the $S H$ arrival, so we cannot rule out other anisotropic symmetries and caus- (a) Radial

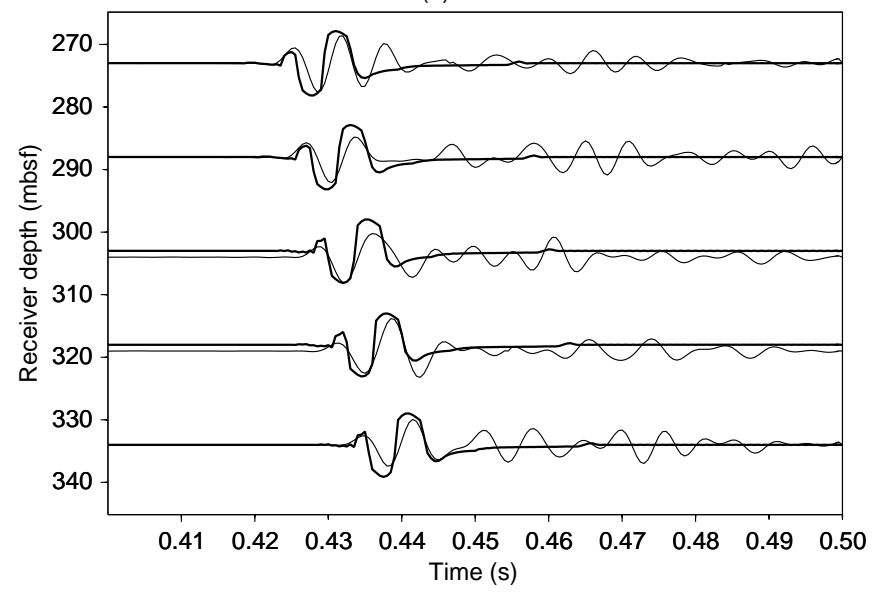

(b) Vertical

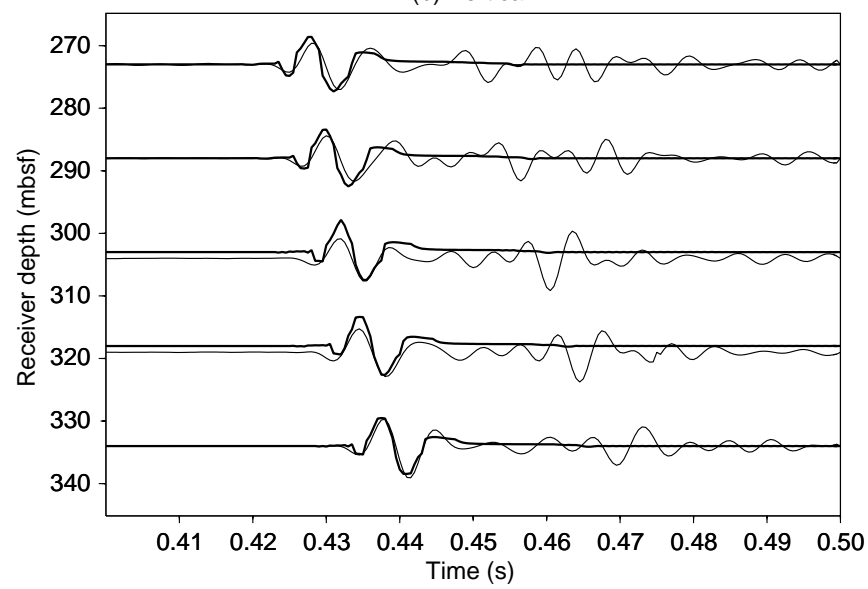

Figure 10. Observed and synthetic seismograms for (A) radial and (B) vertical components of seismometer array for Shot 14. Thin line is observed, and the thick line is synthetic. 
Table 3. Velocity model used in full-waveform one-dimensional modeling of mode-converted $S$-waves in zero-offset VSP.

\begin{tabular}{|c|c|c|c|c|c|c|c|c|}
\hline Layer & $\begin{array}{l}\text { Thickness } \\
(\mathrm{m})\end{array}$ & $\begin{array}{l}\text { Depth to top } \\
(\mathrm{m})^{*}\end{array}$ & $\begin{array}{r}\text { Density } \\
\left(\mathrm{kg} / \mathrm{m}^{3}\right)\end{array}$ & $\underset{(\mathrm{m} / \mathrm{s})}{\operatorname{Minimum}} V_{p}$ & $\underset{(\mathrm{m} / \mathrm{s})}{\operatorname{Maximum}} V_{p}$ & $\underset{(\mathrm{m} / \mathrm{s})}{\operatorname{Minimum}} V_{s}$ & $\underset{(\mathrm{m} / \mathrm{s})}{\operatorname{Maximum}} V_{s}$ & Poisson's ratio \\
\hline 1 & & -5004.7 & 1050 & 1509.00 & 1509.00 & (water) & (water) & 0.500 \\
\hline 2 & 25 & 0 & 1500 & 1580.00 & 1580.00 & 50.00 & 50.00 & 0.499 \\
\hline 3 & 30 & 30 & 1600 & 1600.00 & 1600.00 & 100.00 & 100.00 & 0.498 \\
\hline 4 & 35 & 65 & 1680 & 1614.00 & 1614.00 & 200.00 & 200.00 & 0.492 \\
\hline 5 & 50 & 115 & 1700 & 1677.20 & 1678.10 & 444.49 & 450.06 & 0.462 \\
\hline 6 & 40 & 155 & 1710 & 1714.90 & 1717.00 & 689.20 & 698.40 & 0.404 \\
\hline 7 & 40 & 195 & 1720 & 1747.88 & 1748.25 & 295.79 & 298.48 & 0.485 \\
\hline 8 & 20 & 215 & 1720 & 1746.77 & 1747.80 & 492.73 & 498.95 & 0.457 \\
\hline 9 & 50 & 240 & 1720 & 1748.30 & 1749.22 & 686.18 & 700.00 & 0.425 \\
\hline 10 & 30 & 290 & 1850 & 1817.89 & 1824.06 & 498.44 & 531.39 & 0.459 \\
\hline 11 & 78.2 & 320 & 1670 & 1741.75 & 1743.23 & 346.27 & 380.00 & 0.476 \\
\hline 12 & 5 & 378.2 & 1650 & 1669.38 & 1678.28 & 364.29 & 399.90 & 0.475 \\
\hline 13 & 27.7 & 405.9 & 1700 & 1715.00 & 1715.00 & 460.00 & 460.00 & 0.461 \\
\hline 14 & 5 & 410.9 & 1650 & 1669.38 & 1678.28 & 364.29 & 399.90 & 0.475 \\
\hline 15 & & 410.9 & 1850 & 1837.00 & 1837.00 & 550.00 & 550.00 & 0.451 \\
\hline 11 (Shot 6) & 78.2 & 373.2 & 1670 & 1680.00 & 1680.00 & 520.00 & 520.00 & 0.447 \\
\hline
\end{tabular}

Notes: * = seafloor is zero. Variations used to match ocean-bottom Shots 3-10 are shown at bottom.

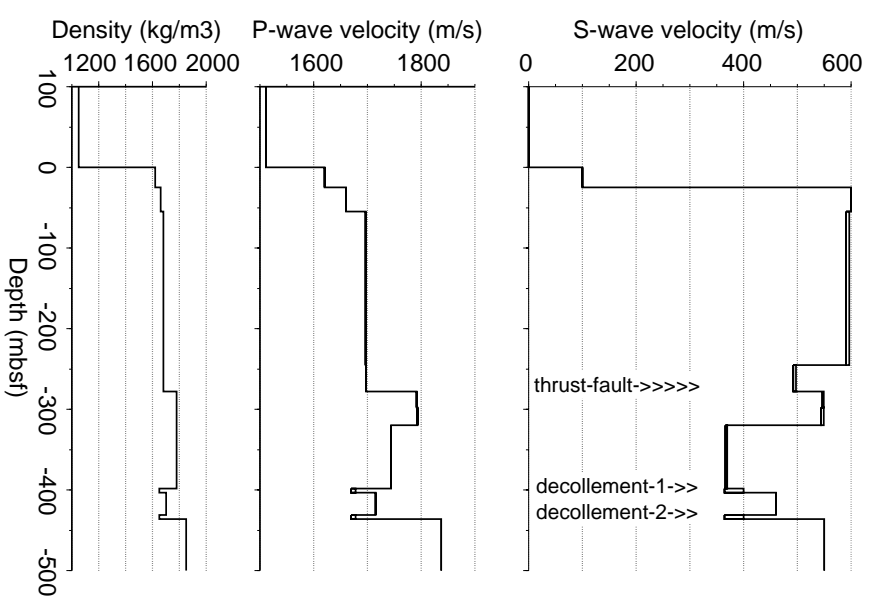

Figure 11 . Density and $P$ - and $S$-wave velocity profiles for synthetic seismogram of zero-offset VSP. Velocity ranges are shown for anisotropic layers.

es of anisotropy, which generate quasi- $S H$-waves (the polarization is not strictly horizontal-transverse in such media) from $P$-waves if they do not have rotational symmetry about a vertical axis. Horizontally aligned cracks or clay grains would not cause this mode conversion (Crampin, 1986). The low $S$-wave velocity $(380 \mathrm{~m} / \mathrm{s})$ just above the décollement in the zero-offset VSP model (Table 3) gave a poor match to the observed mode-converted reflected $S$-wave from Shot 6 $(520 \mathrm{~m} / \mathrm{s})$. Raising the model $S$-wave velocity to $520 \mathrm{~m} / \mathrm{s}$ improved the fit (Fig. 13A). The strong downgoing $S$-waves from the 278- and 298-m interfaces in the zero-offset VSP are not observed in any of the ocean-bottom shot records.

\section{DISCUSSION}

\section{Geological Interpretation of Major Interfaces}

The most important interface in our model is at $278 \mathrm{~m}$ in the zerooffset VSP model and the two-dimensional model, across which $P$ wave velocity increases, but $S$-waves have a velocity inversion. This may be the thrust fault at $290 \mathrm{~m}$ identified by biostratigraphic inversion (Shipboard Scientific Party, 1995b). The fault may not be at the same depth in Hole 949C as the hole lies about $125 \mathrm{~m}$ south of Hole 949B, although there is no strong evidence of southward dip on the crossline of the three-dimensional seismic survey passing through the site (G.F. Moore et al., 1995). The core in which the fault should have appeared was not recovered (Core 156-949B-6X) but the core below (156-949B-7X) showed anomalously high salinity, a rise in bulk density and formation factor, and an increase in calcite relative to the core above (Core 156-949B-5X).

Upgoing waves are reflected from the décollement (at the then base of the hole at $398 \mathrm{mbsf}$ ) and from some $30 \mathrm{~m}$ below that. The zone between is identified as the décollement zone (Shipboard Scientific Party, 1995b) by lithology and deformation similar to those observed in Hole 948C, in which core recovery was more complete. The top of the underthrust sequence (identified from lithology) is at 430.92 mbsf in Core 156-948B-22X but is not marked by a change in bulk or grain density.

\section{Porosity and Fluid Pressure}

The $P$ - and $S$-wave low-velocity zone between $320 \mathrm{mbsf}$ and the décollement at 398 mbsf indicated weak, porous sediments in the lower part of the accretionary wedge, with stronger, more compacted sediments above acting as a permeability barrier. This agrees with the finding of J.C. Moore et al. (1995) from logging while drilling that fluid pressure is above hydrostatic below about $120 \mathrm{~m}$ in Hole 948A. Either an increase in porosity or poorer contact between grains, as suggested by Tobin et al. (1994), may be the reason for low velocities in the overpressured zone.

These two explanations of low velocity in the overpressured zone correspond to an increase in crack aspect ratio (hence porosity) and crack density (hence decrease in grain-to-grain contact), respectively. The effects of increases in crack density and aspect ratio on velocity depend on whether or not the cracks are aligned. If the "intact" sediment has $P$-wave velocity $1730 \mathrm{~m} / \mathrm{s}, S$-wave velocity $550 \mathrm{~m} / \mathrm{s}$, and density $1680 \mathrm{~kg} / \mathrm{m}^{3}$, a crack density (Hudson, 1981) of 0.1 of randomly oriented water-filled cracks with aspect ratio 0.1 (crack porosity 0.01 ) will reduce the velocities to $1714 \mathrm{~m} / \mathrm{s}$ and $529 \mathrm{~m} / \mathrm{s}$. The same cracks, but with aspect ratio 0.001 (crack porosity 0.00001 ), reduce the $S$-wave velocity by the same amount but reduce the $P$-wave velocity much less, to $1721 \mathrm{~m} / \mathrm{s}$.

The same crack density of horizontally aligned cracks would reduce the vertical $P$-wave velocity to $1657 \mathrm{~m} / \mathrm{s}$ and $S$-wave velocity to $500 \mathrm{~m} / \mathrm{s}$. Horizontal velocities are reduced to 1684 and $550 \mathrm{~m} / \mathrm{s}$ respectively. With aspect ratio 0.001 , the same cracks have virtually no effect on the vertical $P$-wave velocity but reduce the vertical $S$-wave velocity to $500 \mathrm{~m} / \mathrm{s}$ (the horizontal velocity of the faster shear wave is $520 \mathrm{~m} / \mathrm{s}$ ). The observed low- $P$ - and $S$-velocity zones may therefore not need a large total porosity, but a strong horizontal alignment of cracks of high aspect ratio.

Horizontally aligned cracks would be expected if the least principal stress were vertical. The $S$-wave data are too poor for the crack 

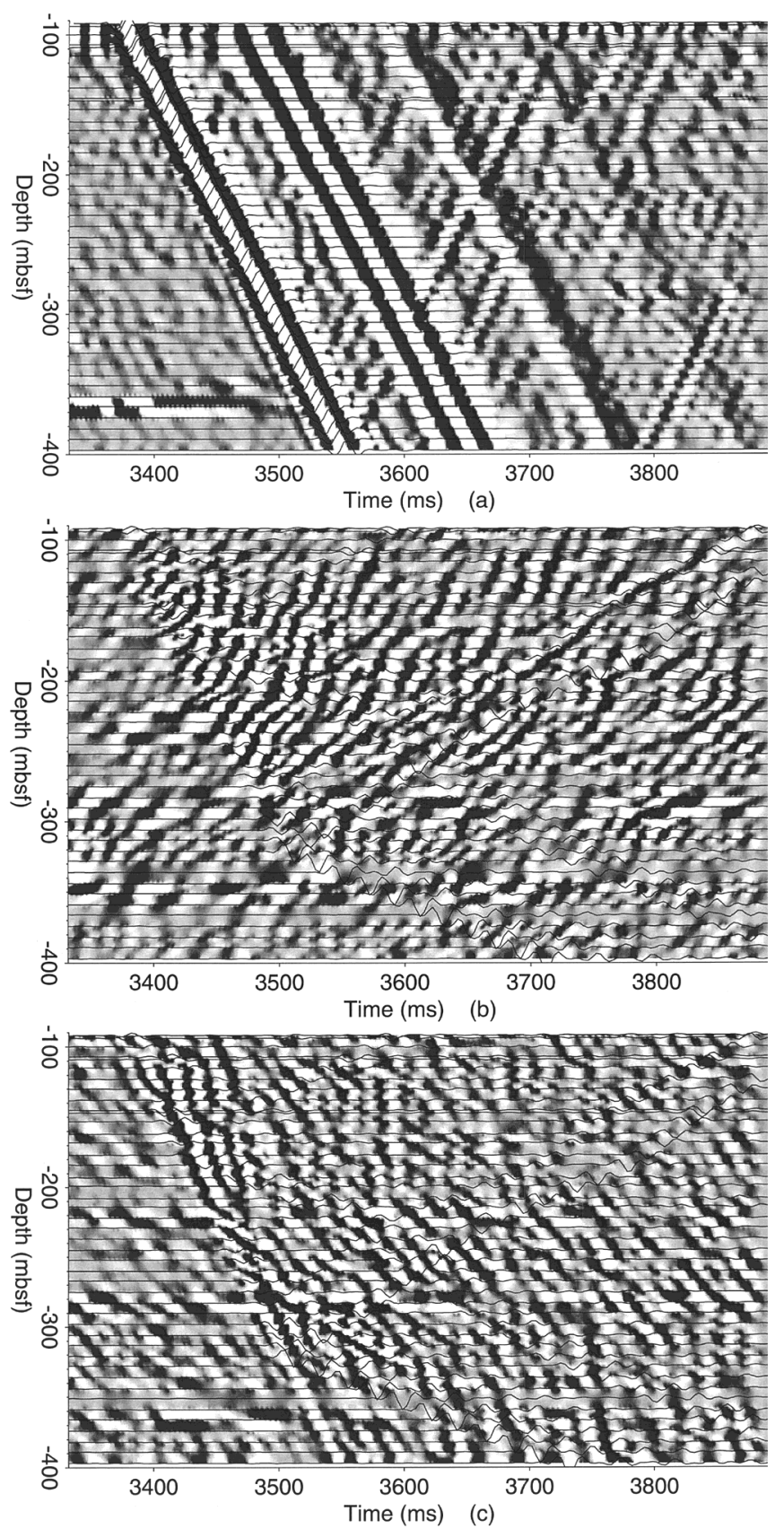

Figure 12. Observed (grayscale shaded-relief) and synthetic (superimposed black wiggles) seismograms of zero-offset VSP. A. Vertical component, illuminated from $250^{\circ}$. B. "Horizontal 1" component of observed seismograms with radial component of synthetics, illuminated from $320^{\circ}$. C. "Horizontal 2" component of observed seismograms with transverse component of synthetics, illuminated from $220^{\circ}$. (Illumination azimuth is measured clockwise from the top of the page).

alignment to be determined unequivocally by modeling birefringence; but the creation of $P$-to $S H$-mode converted waves and of $P$ to $S$-mode conversions in the zero-offset VSP require an orientation of anisotropic symmetry not compatible with horizontal cracks. The discrepancy between the $P$-wave velocities of the zero-offset VSP model and ocean-bottom shot model for the 78-m-thick layer above the décollement could be explained by strong anisotropy caused by vertical or tilted parallel cracks. The velocity difference $(1741 \mathrm{~m} / \mathrm{s}$ for the zero-offset VSP, 1691-1750 m/s for the raytrace model and 1680 $\mathrm{m} / \mathrm{s}$ for the horizontally layered anisotropic model for Shots 3-9) is too large to explain with the Hudson crack model, which works only for crack densities less than 0.1 , but if grain alignment as well as crack alignment contributes to the anisotropy, a larger anisotropy could be achieved. Such conclusions about anisotropy are unconfirmed until the heterogeneity along the ocean-bottom shot raypaths is adequately modeled.

The low $S$-wave velocity and high Poisson's ratio (greater than 0.45 ) indicate sediments with high porosity and possibly low effective stress within the lower part of the accretionary wedge, above the décollement. This in turn implies that in addition to any permeability barrier at the décollement, there must also be a similar barrier or barriers higher in the wedge. These are presumably related to shearing along thrust zones.

\section{CONCLUSIONS}

1. $S$-wave velocities between 100 and 400 mbsf in the Barbados Ridge accretionary complex at Site 949 are low (generally less than $600 \mathrm{~m} / \mathrm{s}$ ), indicating Poisson's ratio above 0.45 .

2 . The $P$-wave velocity at the level of the seismometer array lower position (336-397 m) is lower (about $1680-1743 \mathrm{~m} / \mathrm{s}$ ) than the $1818 \mathrm{~m} / \mathrm{s}$ reported for the zero-offset VSP. $S$-waves are generated by mode conversion of $P$-waves from the zero-offset VSP at the presumed thrust fault at about 298 mbsf. Either anisotropy or dip of the reflector could be causing the mode conversions. They were modeled with parallel fluid-filled cracks with a dip change from $20^{\circ}$ to $70^{\circ}$ across the interface, but other models and crack orientations are possible.

3. Anisotropy with a non-horizontal axis of symmetry is probably responsible for transversely polarized $S$-wave arrivals from the ocean-bottom shots; this was modeled with vertical parallel fluid-filled cracks, but other models are possible and the strike of the cracks was not constrained.

4. A steep $S$-wave velocity gradient in the top $300 \mathrm{~m}$ of the accretionary complex prevents diving $S$-waves of significant amplitude from ocean-bottom shots from reaching a borehole seismometer.

\section{ACKNOWLEDGEMENTS}

We thank Kevin Smith, Gus Gustavson, Eric Meissner, and Dwight Mossman for preparing the explosives and timers; Frank Filice, Hezhu Yin, and Jim Hide for deploying the seismometer array; and all the ODP technicians and the captain and crew of the JOIDES Resolution for their assistance and support. We also thank ODP shore staff, Rachel Proudlove, technicians at Birmingham University, Steve Palmer at Keele University, Bob Whitmarsh at the Institute of Oceanographic Sciences, and Greg Moore and the shipboard scientific party for help, use of equipment, advice, and support. This work was supported by NERC Grants GST/02/834 and GST/02/720 and by the Ocean Drilling Program and Joint Oceanographic Institutions, Inc.

\section{REFERENCES}

Aki, K., and Richards, P.G., 1980. Quantitative Seismology (Vol. 1): New York (W.H. Freeman and Co.).

Bangs, N.L., Shipley, T.H., and Moore, G.F., 1996. Elevated fluid pressure and fault zone dilation inferred from seismic models of the northern Barbados Ridge décollement. J. Geophys. Res., 101:627-642.

Bangs, N.L.B., and Westbrook, G.K., 1991. Seismic modeling of the décollement zone at the base of the Barbados Ridge accretionary complex. $J$. Geophys. Res., 96:3853-3866.

Bangs, N.L.B., Westbrook, G.K., Ladd, J.W., and Buhl, P., 1990. Seismic velocities from the Barbados Ridge Complex: indicators of high pore fluid pressures in an accretionary complex. J. Geophys. Res.,95:8767-8782. 
Benson, G.C., and Kiyohara, O., 1974. Tabulation of some integral functions describing diffraction effects on the ultrasonic field of a circular piston source. J. Acoust. Soc. Am., 55:184-185.

Brown, K.M., Bekins, B., Clennell, B., Dewhurst, D., and Westbrook, G., 1994. Heterogeneous hydrofracture development and accretionary fault dynamics. Geology, 22:259-262.

Bush, I., and Crampin, S., 1991. Paris Basin VSPs: case history establishing combinations of matrix- and crack-anisotropy from modelling shear wavefields near point singularities. Geophys. J. Int., 107:433-447.

Crampin, S., 1984. Effective anisotropic elastic-constants for wave propagation through cracked solids. Geophys. J. Int., 76:135-145.

, 1985. Evaluation of anisotropy by shear-wave splitting. Geophysics, 50:142-152.

, 1986. Anisotropy and transverse isotropy. Geophys. Prosp., 34:94-99.

Dewhurst, D.N., Brown, K.M., Clennell, M.B., and Westbrook, G.K., 1996. A comparison of the fabric and permeability anisotropy of consolidated and sheared silty clay. Engineering Geology, 42: 253-267.

DiSiena, J.P., Gaiser, J.E., and Corrigan, D., 1984. Horizontal components and shear wave analysis of three-component data. In Toksöz, M.N., and Stewart, R.R. (Eds.), Vertical Seismic Profiling Part B: Advanced Concepts. Handbook of Geophysical Exploration, 14B:177-188.

Fisher, A.T., and Hounslow, M.W., 1990. Transient fluid flow through the toe of the Barbados accretionary complex: constraints from Ocean Drilling Program Leg 110 heat flow studies and simple models. J. Geophys. Res., 95:8845-8858.

Fisher, A.T., Zwart, G., and ODP Leg 156 Shipboard Scientific Party, 1996. Relation between permeability and effective stress along a plate-boundary fault, Barbados accretionary complex. Geology, 24:307-310.

Foucher, J.-P., Le Pichon, X., Lallemant, S., Hobart, M.A., Henry, P., Benedetti, M., Westbrook, G.K., and Langseth, M.G., 1990. Heat flow, tectonics, and fluid circulation at the toe of the Barbados Ridge accretionary prism. J. Geophys. Res., 95:8859-8868.

Hudson, J.A., 1980. Wave speeds and attenuation of elastic waves in material containing cracks. Geophys. J. R. Astron. Soc., 64:133-150.

- 1986. A higher order approximation to the wave propagation constants for a cracked solid. Geophys. J. R. Astron. Soc., 87:265-274.

Kirk, R.E., Robertson, K., Whitmarsh, R.B., and Miles, P.R., 1991. A technique for conducting seismic refraction experiments on the ocean bed using bottom shots. Mar. Geophys. Res., 13:153-160.

Liu, E., Crampin, S., and Yardley, G., 1990. Polarization of reflected shear waves. Geophys. Res. Lett., 17:1137-1140.

Mascle, A., Moore, J.C., et al., 1988. Proc. ODP, Init. Repts., 110: College Station, TX (Ocean Drilling Program).

McCann, C., Assefa, S., McCann, D.M., and Jackson, P.D., 1989. In-situ borehole measurements of compressional and shear wave attenuation in Oxford Clay. Scientific Drilling, 1:11-20.

McCann, C., and Sothcott, J., 1992. Laboratory measurements of the seismic properties of sedimentary rocks. In Hurst A., Worthington, P.F., and Griffiths, C. (Eds.), Geological applications of wireline logs: Bath, UK (Geological Society), 2:285-297.

Moore, G.F., Zhao, Z, Shipley, T.H., Bangs, N., and Moore, J.C., 1995. Structural setting of the Leg 156 area, northern Barbados Ridge accre- tionary prism. In Shipley, T.H., Ogawa, Y., Blum, P., et al., Proc. ODP, Init. Repts., 156: College Station, TX (Ocean Drilling Program), 13-27.

Moore, J.C., Mascle, A., Taylor, E., Andreieff, P., Alvarez, F., Barnes, R., Beck, C., Behrmann, J., Blanc, G., Brown, K., Clark, M., Dolan, J.F., Fisher, A., Gieskes, J., Hounslow, M., McLellan, P., Moran, K., Ogawa, Y., Sakai, T., Schoonmaker, J., Vrolijk, P., Wilkens, R.H., and Williams, C., 1988. Tectonics and hydrogeology of the northern Barbados Ridge: results from Ocean Drilling Program Leg 110. Geol. Soc. Am. Bull., 100:1578-1593.

Moore, J.C., Shipley, T.H., Goldberg, D., Ogawa, Y., Filice, F., Fisher, A., Jurado, M.-J., Moore, G.F., Rabaute, A., Yin, H., Zwart, G., Brückmann, W., Henry, P., Ashi, J., Blum, P., Meyer, A., Housen, B., Kastner, M., Labaume, P., Laier, T., Leitch, E.C., Maltman, A.J., Peacock, S., Steiger, T.H., Tobin, H.J., Underwood, M.B., Xu, Y., and Zheng, Y., 1995. Abnormal fluid pressures and fault-zone dilation in the Barbados accretionary prism: evidence from logging while drilling. Geology, 23:605-608.

Papadakis, E.P., 1975. Ultrasonic diffraction from single apertures with application to pulse measurements and crystal physics. In Mason, W.P., and Thurston, R.N. (Eds.), Physical Acoustics, 11:1-152.

Peacock, S., McCann, C., and Sothcott, J., 1991. Vertical seismic profiles in Oxford clay at Purton, near Swindon. Geophys. J. Int., 104:683. (Abstract)

Shipboard Scientific Party, 1995a. Site 948. In Shipley, T.H., Ogawa, Y., Blum, P., et al., Proc. ODP, Init. Repts., 156: College Station, TX (Ocean Drilling Program), 229-636.

, 1995b. Site 949. In Shipley, T.H., Ogawa, Y., Blum, P., et al., Proc. ODP, Init. Repts., 156: College Station, TX (Ocean Drilling Program) 637-961.

Shipley, T.H., Moore, G.F., Bangs, N.L., Moore, J.C., and Stoffa, P.L., 1994. Seismically inferred dilatancy distribution, northern Barbados Ridge décollement: implication for fluid migration and fault strength. Geology, 22:411-414.

Shipley, T.H., Ogawa, Y., Blum, P., et al., 1995. Proc. ODP, Init. Repts., 156: College Station, TX (Ocean Drilling Program).

Taylor, D.B., 1992. Aniseis manual: Edinburgh (Macroc Ltd./Applied Geophysical Software Inc.).

Tobin, H.J., Moore, J.C., and Moore, G.F., 1994. Fluid pressure in the frontal thrust of the Oregon accretionary prism: experimental constraints. Geology, 22:979-982.

Viggiani, G., and Atkinson, J.H., 1995. Interpretation of bender element tests. Géotechnique, 45:149-154.

Westbrook, G.K., 1991. Geophysical evidence for the role of fluids in accretionary wedge tectonics. Philos. Trans. R. Soc. London A, 335:227-242.

Westbrook, G.K., Campbell, R.J., Graham, D.P., O'Neill, P.S., Mountney, N.P., Peirce, C., Whitmarsh, R.B., Kirk, R.E., Saunders, M.R., White, D., Smith, W.K., Woodley, C.H., Davies, M.A., Lewis, D., Dunster, D., Paulson, C.J., and Jones, J.L., 1993. RRS Charles Darwin Cruise 75, 6th January-1st February 1993: Birmingham, UK (University of Birmingham and NERC).

\section{Date of initial receipt: 6 February 1996 \\ Date of acceptance: 1 August 1996 \\ Ms 156SR-033}
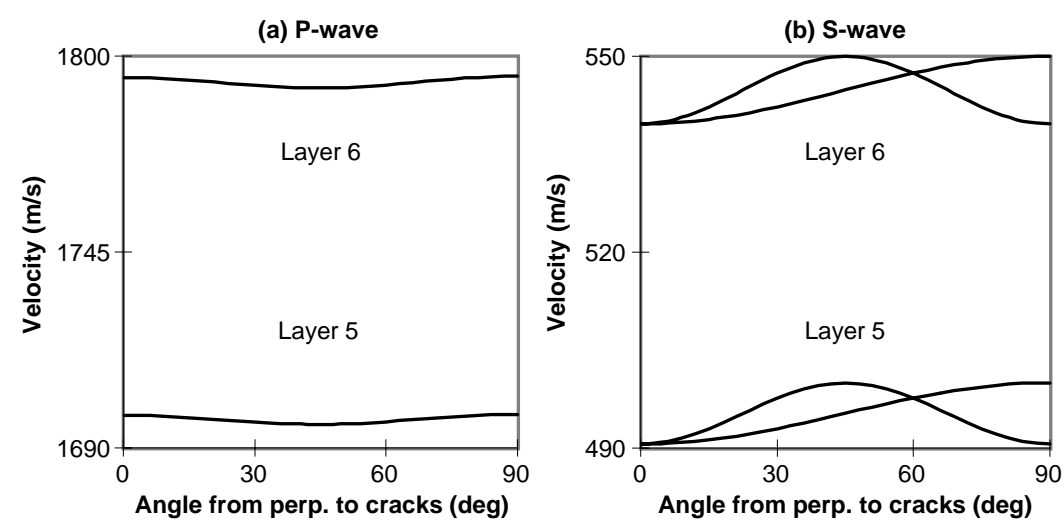

Figure 13. Velocity variations in cracked Layers 5 and 6 , on either side of "thrust fault" at $298 \mathrm{~m}$ (Table 3). (A) $P$ wave and (B) $S$-wave, showing $S$-wave splitting. The faster split $S$-wave at $90^{\circ}$ to the crack normal is polarized parallel to the cracks. Phase velocity is shown; deviation of group from phase velocity is slight in this model. 

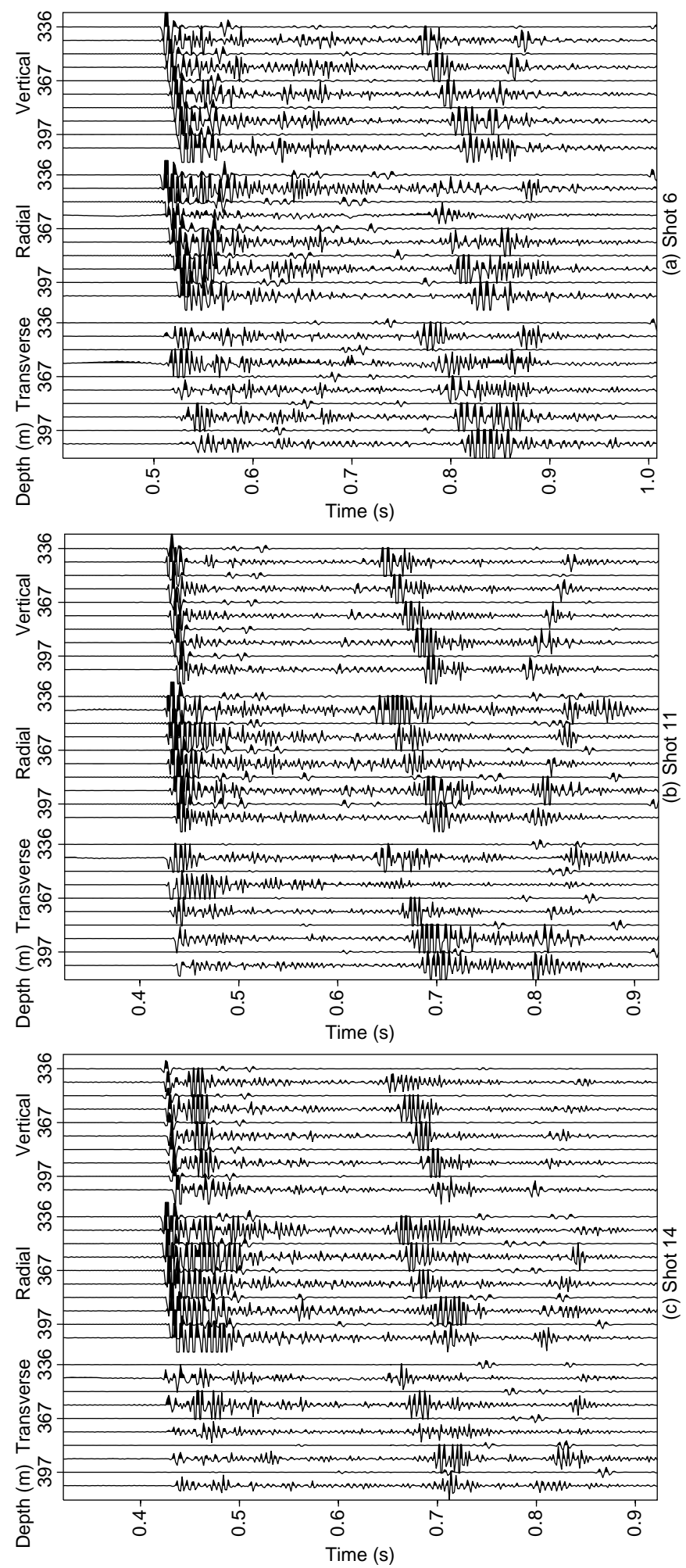

Figure 14. Observed and synthetic seismograms for ocean-bottom shots. The synthetic trace is shown above the observed for each depth. A. Shot 6 . B. Shot 11 . C. Shot 14 


\section{APPENDIX}

\section{LABORATORY MEASUREMENTS OF SHEAR WAVES IN CORE SAMPLES}

Shortcomings in Shipboard Measurements of $S$-wave Velocity

There were three major shortcomings in the method of measuring the $S$ wave velocities presented in the Initial Reports:

1. The wavelengths generated by the "bender" transducers were longer than the specimen size. The standard physical properties specimens, on which the measurements were done, were 25 - to 35-mm cubes. For the transducer dominant frequency of $2 \mathrm{kHz}$ and $S$-wave velocities of $100-800 \mathrm{~m} / \mathrm{s}$, wavelengths are $50-400 \mathrm{~mm}$.

2. The "first break" picked as the arrival of the $S$-wave from the bender transducers may be a compressional mode. Viggiani and Atkinson (1995) found that choosing the first peak of the waveform gave dynamic shear moduli closer to those obtained from transit time/length graphs of uniform test specimens, meaning that shear moduli based on first-break arrival times were too high.

3. No correction was made for the diffraction effects caused by the finite size of the transducer (Papadakis, 1975; Benson and Kiyohara, 1974).

The shipboard measurements thus gave velocities that were too high.

\section{Method}

We have used whole-round specimens to address these problems:

1. They are slightly larger (travel paths were $16-44 \mathrm{~mm}$ ).

2. The first peak rather than the first break of the bender transducer signal was picked.

3. Results from the bender transducers were compared with those from two flat-face piezoelectric $S$-wave transducers (Panametrics v154 2.25 $\mathrm{MHz} / 0.5,13$-mm-diameter face).

4. Diffraction corrections for finite size of both bender and flat-face transducers were applied (Benson and Kiyohara, 1974; McCann and Sothcott, 1992). The finite size causes a frequency and pathlengthdependent phase shift (relative to the phase for a point source), which affects traveltimes.

The measurements were made at room temperature and pressure to simulate shipboard conditions. For the bender measurements, the procedure followed on the ship for Leg 156 was used. A correction for system delay time $(20.61 \mu \mathrm{s})$, based on shipboard calibration measurements using wax standards, was subtracted from each traveltime. The diffraction correction, based on the width of the bender blade, was added to the traveltime (McCann and Sothcott, 1992). It was $8-68 \mu$ s or up to $25 \%$ of the total traveltime.

Measurements were made with the piezoelectric flat-face transducers by placing them against opposite sides of the specimen with their polarization directions parallel and picking $P$ - and $S$-wave first breaks on a 50 -fold stacked trace on the screen of a digital storage oscilloscope. Transducer separation was measured with Vernier calipers placed on the back faces of the transducers and corrected for the transducer thickness $(2 \times 16 \mathrm{~mm})$. Diffraction corrections of 3-14 $\mu$ s (less than $10 \%$ of traveltime) were applied. Only one specimen (interval 156-948C-14X-6, 79-92 cm) was large enough for measurements to be made in the horizontal (across-core) direction. All other measurements were made in the vertical (along-core) direction. Errors are about $1 \%$ in specimen length and $2 \%$ in traveltime.

Results

Velocities

All the velocities (Table A1) are much lower than those from shipboard measurements (Shipboard Scientific Party, 1995a, 1995b), because of picking the first peak rather than the first break of the waveform and adding the diffraction correction. The velocities measured with the $2.5 \mathrm{MHz}$ transducers are higher than those from the benders.

The one specimen for which measurements in two directions were made (interval 156-948C-14X-6, 79-92 cm) showed higher velocities for the horizontally polarized, horizontally traveling wave than for vertically polarized or vertically traveling waves.

Waveforms

The flat-face transducer generates a $P$-wave of period $0.4 \mu$ s (frequency $2.5 \mathrm{MHz}$ ) and an $S$-wave of period $30-70 \mu$ s (frequency $3-10 \mathrm{kHz}$ ). The benders give no $P$-wave and $S$-waves of period $100-330 \mu$ s (frequency $3-10 \mathrm{kHz}$ ). Wavelengths from the benders are $6-33 \mathrm{~mm}$ and for the flat face transducers, $7-12 \mathrm{~mm}$.

Loading the faces reduces the dominant frequency of a flat-face transducer, but the very large reduction from the nominal $2.5 \mathrm{MHz}$ implies a low $Q$ for the cores. If the velocity difference between the bender and flat-face transducer measurements is attributed to attenuation-induced dispersion, a $Q$ of 1.0 1.2 is derived (Aki and Richards, 1980). This is probably an underestimate, but it supports the interpretation of low $S$-wave $Q$ in the accretionary wedge sediments. A low $S$-wave $Q$ does not imply a low $P$-wave $Q$ : Peacock et al. (1991) found $S$-wave $Q$ of $10-20$ at $50 \mathrm{~Hz}$ from a shallow VSP in overconsolidated Oxford clay where McCann et al. (1989) found $P$-wave $Q$ of 21-119 at $1 \mathrm{kHz}$.

\section{Conclusions}

1. The shipboard measurements of $S$-wave velocities made with face-toface bender transducers (i.e., all except those on mudline cores) from Holes 948C and 949B are overestimates; true velocities are 115-260 $\mathrm{m} / \mathrm{s}$

2. $V_{p} / V_{s}$ and Poisson's ratio are even higher than stated in the Initial Report (above 0.49).

3. $S$-wave $Q$ in the specimens is very low.

These conclusions would be modified by making the measurements at in situ values of effective pressure. Velocity and $Q$ would probably rise, even if the effective pressure is low.

Table A1. $S$-wave velocities in whole-round core samples from Holes $948 \mathrm{C}$ and 949B.

\begin{tabular}{|c|c|c|c|c|c|c|c|c|c|c|}
\hline $\begin{array}{l}\text { Core, section, } \\
\text { interval }(\mathrm{cm})\end{array}$ & $\begin{array}{l}\text { Depth } \\
\text { (mbsf) }\end{array}$ & $\begin{array}{c}\text { Direction } \\
\text { of travel/ } \\
\text { polarization }\end{array}$ & $\begin{array}{l}\text { Transducer } \\
\text { separation } \\
(\mathrm{mm})\end{array}$ & $\begin{array}{l}S \text {-wave velocity } \\
\text { (bender) } \\
(\mathrm{m} / \mathrm{s})\end{array}$ & $\begin{array}{l}S \text { wavelength } \\
(\mathrm{mm})\end{array}$ & $\begin{array}{c}\text { Direction } \\
\text { of travel/ } \\
\text { polarization }\end{array}$ & $\begin{array}{c}\text { Transducer } \\
\text { separation } \\
(\mathrm{mm})\end{array}$ & $\begin{array}{l}S \text {-wave velocity } \\
\text { (flat PZT) }\end{array}$ & $\begin{array}{l}S \text { wavelength } \\
(\mathrm{mm})\end{array}$ & $\begin{array}{c}S \text {-wave Q } \\
\text { from } \\
\text { dispersion }\end{array}$ \\
\hline $\begin{array}{l}\text { 156-949B- } \\
22 \mathrm{X}-3,10-13\end{array}$ & 430.45 & $\begin{array}{l}\mathrm{zx} \\
\mathrm{zy}\end{array}$ & $\begin{array}{l}34.485 \\
34.185\end{array}$ & $\begin{array}{l}115.8 \\
129.9\end{array}$ & $\begin{array}{l}29.96 \\
25.79\end{array}$ & $\mathrm{z}$ & 3.545 & 179.2 & 12.20 & $\begin{array}{l}1.2 \\
1.2\end{array}$ \\
\hline $\begin{array}{l}\text { 156-949B- } \\
22 \mathrm{X}-3,0-5\end{array}$ & 430.4 & $\begin{array}{l}\mathrm{zx} \\
\mathrm{zy}\end{array}$ & $\begin{array}{l}15.42 \\
15.12\end{array}$ & $\begin{array}{l}109.8 \\
121.2\end{array}$ & $\begin{array}{l}19.52 \\
16.50\end{array}$ & $\mathrm{z}$ & 1.68 & 196.4 & 7.25 & $\begin{array}{l}1.1 \\
1.1\end{array}$ \\
\hline $\begin{array}{l}\text { 156-948C- } \\
14 X-6,79-92\end{array}$ & 544.39 & $\begin{array}{l}\mathrm{zx} \\
\mathrm{zy} \\
\mathrm{xy} \\
\mathrm{xz}\end{array}$ & $\begin{array}{l}30.335 \\
30.035 \\
42.87 \\
42.57\end{array}$ & $\begin{array}{l}114.0 \\
193.5 \\
228.8 \\
182.3\end{array}$ & $\begin{array}{l}38.46 \\
33.96 \\
26.41 \\
31.99\end{array}$ & $\begin{array}{l}\mathrm{z} \\
\mathrm{xy}\end{array}$ & $\begin{array}{l}3.205 \\
4.42\end{array}$ & $\begin{array}{l}211.2 \\
217.8\end{array}$ & $\begin{array}{l}10.25 \\
12.05\end{array}$ & $\begin{array}{r}1.3 \\
-4.6\end{array}$ \\
\hline $\begin{array}{l}156-949 \mathrm{~B}- \\
1 \mathrm{X}-6,57-65\end{array}$ & 367.97 & $\begin{array}{l}\mathrm{zx} \\
\mathrm{zy}\end{array}$ & $\begin{array}{l}22.935 \\
22.635\end{array}$ & $\begin{array}{l}133.6 \\
166.9\end{array}$ & $\begin{array}{l}30.85 \\
17.34\end{array}$ & $\mathrm{z}$ & 2.425 & 260.2 & 8.40 & 1.0 \\
\hline
\end{tabular}

